\title{
pro.posıções
}

$e$-ISSN 1980-6248

http://dx.doi.org/10.1590/1980-6248-2017-0008

DOSSIÊ: "Didática e formação de professores"

\section{Professional knowledge building in teacher education: some reflections based on Gur-Ze'ev ${ }^{12}$}

\section{A construção do conhecimento profissional na formação de professores: algumas reflexões a partir de Gur-Ze'ev}

\author{
Alexandre Anselmo Guilherme (i) \\ Valderez Marina do Rosário Lima (ii) \\ Rosana Maria Gessinger (iii)
}

\begin{abstract}
(i) Pontifícia Universidade Católica do Rio Grande do Sul - PUCRS, Porto Alegre, RS, Brasil. https://orcid.org/0000-0003-4578-1894, alexandre.guilherme@pucrs.br

(ii) Pontifícia Universidade Católica do Rio Grande do Sul - PUCRS, Porto Alegre, RS, Brasil. https://orcid.org/0000-0002-2676-5840, valderez.lima@pucrs.br

(iii) Pontifícia Universidade Católica do Rio Grande do Sul - PUCRS, Porto Alegre, RS, Brasil. rosana.gessinger@pucrs.br
\end{abstract}

Abstract:
This article critically discusses the topic of professional knowledge in teacher
education through the lenses of Ilan Gur-Ze'ev's counter-education. It is based on
a study investigating how professional knowledge building evolves through written
reflections, examining the development of professional identity in the context of a
course in an undergraduate teacher education course in Brazil. The research's
findings demonstrate that students gained an awareness of the potential that
teaching and learning activities have for the development of concepts about the
teaching profession, leading to the strengthening of their professional identity as
future teachers and as what Gur-Ze'ev called 'improviser-teacher'.
Keywords: Gur-Ze'ev; teacher education; professional knowledge building;
improviser-teacher

\footnotetext{
${ }^{1}$ Copy editor: José Pereira Queiroz - ze.pereira.queiroz@gmail.com

${ }^{2}$ Bibliographic and editorial normalization: Vera Bonilha - verabonilha@yahoo.com.br
} 


\title{
pro.posições
}

$e$-ISSN 1980-6248

http://dx.doi.org/10.1590/1980-6248-2017-0008

\begin{abstract}
Resumo:
Este artigo discute criticamente o tema do conhecimento profissional na formação de professores através das lentes da contraeducação de Ilan Gur-Ze'ev. Baseia-se em um estudo que investiga como a formação de conhecimentos profissionais evolui através de reflexões escritas, examinando o desenvolvimento da identidade profissional no contexto de uma disciplina de um curso de graduação em Pedagogia no Brasil. Os resultados demonstram que os estudantes ganharam consciência do potencial que as atividades de ensino e aprendizagem têm para o desenvolvimento de concepcōoes sobre a profissão docente, levando ao fortalecimento de sua identidade profissional como futuros professores e ao que Gur-Ze'ev chamou de "professor-improvisador".
\end{abstract}

Palavras-chave: Gur-Ze'ev, formação de professores, construção do conhecimento profissional; professor-improvisador

\section{Introduction}

It is a common belief that if an individual has knowledge of a specific area and an acquaintance with some teaching skills, then this is sufficient to allow that individual to teach. This idea is further emphasised through cultural references, such as when we find examples of individuals from cinema, sports and literature that have become teachers without any pedagogical preparation; for instance: Boris Becker who won six grand slams and now coaches the world number one Novak Djokovic; Diego Maradona who was captain of Argentina's World Cup winning in 1986 and later became coach of Argentina's national team-it can be argued that they had a great deal to teach the athletes working with them. It is also worth noting that this was common practice in British private schools (i.e. British Public Schools), which were always free to employ unqualified teachers, most of which were alumni with a relevant degree (cf. https://fullfact.org/education/unqualified-teachers/). This "pedagogical common-sense" is a reductionist understanding of teaching that ignores the complexities involved; that is, the knowledge gained through experience that characterizes teaching, which becomes fundamental for the professional teacher identity. Related to this is the issue that prospective teachers often have of their own understanding of the teaching profession. These concepts are often constructed by various cultural influences, such as their experiences as students when they come in contact with the teaching models used by their teachers, as well as 


\section{pro.posições}

$e$-ISSN 1980-6248

http://dx.doi.org/10.1590/1980-6248-2017-0008

the aforementioned "pedagogical common-sense". This means that without a proper critical review, the actions of future teachers will be, at least partly, based on their personal theories about teaching, as evidenced by this study. It can be argued that revising these ideas about teaching and about the teaching profession, initiating a movement towards a new and richer understanding, represents a great challenge that should be experienced in the first years of teacher education (Grillo, 2001).

Based on this, we defend, in this article, that the experiences gained during the first years of teacher education are essential for the construction of future teachers' professional identity because, without minimising the importance of other periods, it is this moment that provides them with the opportunity to confront pedagogical issues, which until then were being answered by referring to "pedagogical common-sense" and without proper reflexions and in-depth analysis (Grillo, 2001). It follows that the content and actions within any given course need to take this into account; that is, those teaching in teacher education courses must bear this in mind when designing activities and when regarding the theoretical and practical framework adopted by the course.

It is from this background that our study took place, aimed at examining the development of professional teacher identity in the early years of teacher education. The main objective of the research was to investigate the evolution of professional teaching knowledge resulting from activities and reflections carried out in the Didactics course for students in the early years of a teacher education course. Thus, the research question guiding this study was: How do activities that were intentionally conceived to promote reflexions about initial concepts of teaching contribute to the construction and reformulation of the professional knowledge of prospective teachers in their early training stage? This article is organized in four sections. In the first section, we present the theoretical framework, which draws inspiration from Ilan Gur-Ze'ev's work, the important Israeli philosopher of education. In the second section, we present the methodology, detailing elements of the Didactics course, characterising the participants, the data collection instrument, and the method of analysis that was used. In the third section, we present the results and critically analyse them in three inter-related a priori categories, which were conceived based on Gur-Ze'ev's work; these are: (1) the recognition of the other; (2) the classroom as a space for exchange and dialogue; and (3) critical positioning. In the last section, we conclude the article, returning to the problem at hand and making our final considerations. 


\section{pro-posıções \\ $e$-ISSN 1980-6248 \\ Theoretical foundation - Ilan Gur-Ze'ev's concepts of counter- education and improviser-teacher}

http://dx.doi.org/10.1590/1980-6248-2017-0008

Ilan Gur-Ze'ev, the important Israeli philosopher of education and professor at the University of Haifa, who passed away unexpectedly in 2012, provides us with very interesting work in this area, and as such we have opted to refer to his work as the theoretical cornerstone for our study. This author is not well-known in Brazil, with only two of his original works translated (Gur-Ze'ev, 2002, 2006); however, he was a very prominent scholar in this area and was part of a group of theorists working on critical pedagogy in the Englishspeaking world, which included Nicholas Burbules, Gert Biesta, Peter McLaren, and Michael Apple. Gur-Ze'ev was the author of numerous articles and books, of which Beyond the modernpostmodern struggle in education: Toward counter-education and enduring improvisation (Gur-Ze'ev, 2007) and Critical theory and critical pedagogy today: Toward a new critical language in education (Gur-Ze'ev, 2005) are certainly worth mentioning for the theoretical impact they had in the field of education and critical pedagogy. More specifically, and of particular relevance to this article, is Gur-Ze'ev's notions of counter-education and improviser-teacher. We will turn our attention to these later in this section, after we have discussed the issue of professional teacher identity.

Several authors have theorised about the knowledge required for teaching (Alarcão, 2000; Grillo, 2004; Liston \& Zeichner, 1997; Pimenta, 2012; Porlán \& Rivero, 1998; Schön, 2000; Shulman, 2005; Tardif, 2002). Despite the use of various terminologies, there is a general consensus among these scholars regarding some characteristics, which are represented by three pillars. There is a scientific pillar, referring to the concepts of a discrete area of knowledge; pedagogical pillar, related to the values and purposes of education; and the experiential pillar, the practical knowledge gained through teaching experiences. The right balance between these three pillars and the willingness of the teacher in training to learn are fundamental for appropriate educational processes that are in keeping with the demands of the contemporary world (Tardif, 2002).

Also, it can be argued that this theoretical framework is fundamental for the individual's formation of his or her professional teaching identity. Pimenta (2012, p. 20) points out that professional teaching identity is also built by the meaning that each teacher, as an actor and author, confers to the teaching activity in their daily lives based on their values, their 


\section{pro.posições}

$e$-ISSN 1980-6248

http://dx.doi.org/10.1590/1980-6248-2017-0008

ways of being in the world, their life histories, their understandings of this knowledge, of anxieties and yearnings, of the meaning that they give, in their lives, to being a teacher.

Beja and Rezende (2014), corroborated by Pimenta (2012) and Nóvoa (1995), emphasise that the education of teachers is influenced by many variables, but especially by being students at different schooling stages, including the experiences during their undergraduate degrees. Thinking critically about these models and evaluating them is a prerequisite for developing prospective teachers' understanding of the profession because, as it has already been said, their notions are coloured by the unreflective ideas about teaching based on their previous experiences, characterized by "pedagogical common-sense" (Lima \& Grillo, 2008).

It is clear how important the early years in teacher education courses are because this is the period when the trainee will engage in activities specifically created to encourage critical reflection on the teaching profession, which will hopefully provide the student with a richer and deeper understanding of that profession. These critical activities have a clear pedagogical value because they place reflection at the centre of the process and it is through this that future teachers perceive the weaknesses and contradictions in their concepts of the teaching practice. These actions also allow prospective teachers to debate with their lecturers and colleagues, which might encourage coming into contact and critically analysing different theories on teacher education.

Morosini and Comarú (2009, p. 72) draw our attention to the importance of reflection in vocational education, stating that this is a process of construction, reconstruction, and transformation of concepts. That is to say, the development of the professional identity of teachers happens throughout their professional life, and for some theorists real practical experiences are more fundamentally transformative experiences than those happening during the early years of teacher education (Gomez, 2015). It can be argued, however, that it is the experiences in the early years of teacher education that provide the first set of elements for the organisation and reorganisation of the professional identity of teachers, if they are constructed carefully with the clear intention of helping future teachers critically review their concepts of the role of the teacher.

Gur-Ze'ev's concepts of counter-education and of "improviser-teacher" serve as the theoretical framework for this study. Gur-Ze'ev was influenced by Paulo Freire's thought and 


\section{pro.posıções}

$e$-ISSN 1980-6248

http://dx.doi.org/10.1590/1980-6248-2017-0008

develops some important criticisms of his version of critical pedagogy. According to GurZe'ev, critical pedagogy faces two major problems: (1) it creates a narrow view of reality, stemming from a limited understanding of oppression, and in so doing creates an equally limited form of utopia: a utopia of which the foundations are unsure, but which must, nonetheless, be sought; (2) as a consequence of this, critical pedagogy becomes incapable of being critical of itself because it seeks to establish this utopia at all costs, losing its power of self-criticism along the way (Gur-Ze'ev, 2005; Tubbs, 2005; Yaakoby, 2012, p. 53). Critical pedagogy seeks to change the world, to revolutionize the real world, and to implement utopian visions in the name of a more just and liberal society. However, there is a potential problem as once a utopian ideal is created (and we have established that the utopia itself is based on poor understanding) and a goal is set to be achieved, then it becomes impossible to criticize and revise the ideal because doing so puts the project in danger. That is to say, the sought-after utopia goes from being an end to be achieved to becoming the foundational principle on which an entire methodology and philosophy is constructed. This creates a circularity problem for critical pedagogy.

It is this potential for a lack of self-criticism embedded in critical pedagogy that is something fundamentally problematic for Gur-Ze'ev (2010a). As a response he proposes counter-education, a term that he coined, which is education that is:

conscious of its impossibility and that has neither an antitoxin nor an emancipating mantra to sell. It has no safe haven, no spiritualistic moral nor any unsuspecting guide to facilitate the hospitality of a cloud of self-forgetfulness which will become a condolence strong enough to appear as liberation. (p. 20)

Gur-Ze'ev's counter-education alternative does not propose an unachievable utopia, instead, it aims to remain critical and, most importantly, self-critical. To explain this, GurZe'ev uses the metaphor of "a caravan" to describe the continuous critical and dialogical process that should be undertaken in all learning and education. Gur-Ze'ev (2011) says:

In the Hebrew language "Orcha" means a convoy of camels and humans with their belongings moving in an endless desert towards their destiny. The "Orcha" is an improvised movement that is to find/create its own destiny. ...The "Orcha" is never totally determined by territorial sovereignty, not even by commanding knowledge and people. It is a kind of togetherness-inmovement". (pp. 38-39) 


\section{pro.posıções}

$e$-ISSN 1980-6248

http://dx.doi.org/10.1590/1980-6248-2017-0008

This leads us to the role of the teacher in Gur-Ze'ev's counter education. Countereducation conceives of the teacher as the "improviser." Gur-Ze'ev's "improviser-teacher" is critical, encourages criticism, and believes everything can be the subject of critique, and this process brings about changes in reality; however, the "improviser-teacher" does not offer positive utopias, such as Freire's liberation by enlightening the oppressed poor. Thus, the "improviser-teacher" is not an improviser in the sense of being unprepared or amateur, but in the sense that he or she has a developed sense of criticism and self-critique, so he or she is able to deal with most situations, with the "uncertainty of the classroom". Furthermore, GurZe'ev (2010b) says that the "improviser" and counter-education display an:

openness and uncontrolled... creativity that is responsible and generous towards the Other and reaches out to the unknown and to self-overcoming as self-constitution; without an egoisticoriented 'I' initiating the colonization of the Other, the response to the otherness or the self-sacrifice of the victimizing kind [emphasis added]. The otherness of the other, the insecurity, the nonconsensual and refusal of the self-evidence and other manifestations of the invitation to the "home-returning" project. (p. 43)

Gur-Ze'ev calls for a responsibility towards the Other, a responsibility that goes beyond culture, politics, gender, and any other kinds of difference (Yaakoby, 2012, p. 93). And in order for one to be critical about issues and about oneself, as well as to recognize the Other in the Other's difference, there must be a place that is propitious to exchanges, to dialogue with the Other about issues; that is to say, there is a need for dialogical spaces.

Based on this, we note that some fundamental characteristics for the emergence of the "improviser-teacher" are the following: critical positioning, the recognition of the Other, and the existence of dialogical spaces. Thus, in this study we have set-up as a priori categories the following ones, based on Gur-Ze'ev's theory: (1) Critical positioning-the "improviserteacher" is always critical and encourages criticism; (2) The recognition of the other-the "improviser-teacher" recognises the Other in the Other's difference; (3) The classroom as a space for exchanges and dialogue - the "improviser-teacher" requires a dialogical space to exchange ideas and criticisms with Others. 


\section{pro.posıções}

$e$-ISSN 1980-6248

http://dx.doi.org/10.1590/1980-6248-2017-0008

\section{Methodology}

Qualitative research can be characterised by a naturalistic and constructivist approach (Denzin \& Lincoln, 2006; Flick, 2009; Guba \& Lincoln, 1994; Stake, 2011; Triviños, 1987) to analyse a concrete situation, which must be described and interpreted by a person's own experience of it. The context of our study is a Didactics course, which is compulsory for all students of the 12 undergraduate degrees offered by a private university situated in the south of Brazil. We note that this is a very rich and complex environment given the presence of individuals from several academic areas, which favours debate among students because of their different points of view.

The participants in this study were students enrolled in two classes of Didactics in the first semester of 2016, totalling 71 students of the following undergraduate courses: Biology, Physical Education, Philosophy, Physics, Geography, History, Language Arts: Portuguese, Language Arts: English, Mathematics, and Chemistry.

The classes in this module merge theory and practice, and students are encouraged to play a double role. They are encouraged to study, debate, and engage in activities as well as to distance themselves, critically analysing their routine and events that "just happened" in the classroom. These actions are intentionally created by teachers' in the module and guided by four inter-related principles, which were established by the lectures: (1) the commitment of the future teachers with the creation and development of pedagogical work; (2) collaborative work (3) questioning as a way of triggering dialogue; and (4) critical reflection as an element of the teaching practice.

The theoretical framework of this course focuses on the three dimensions that configure the classroom: learning, teaching, and evaluation (Lima \& Grillo, 2008). It also proposes practices which are consistent with the theoretical models studied, promoting the study of epistemological theories that underlie pedagogical models (Becker, 1994; Lima \& Grillo, 2008; Porlán, 1998); of the theoretical knowledge and practical skills of teachers (Kollas, Marques, Megier, \& Frison , 2013; Puentes, Aquilino, \& Armindo 2009); as well as of planning and projects (Fonte, 2014; Fusari, 1990; Hernández, 1998).

Regarding teaching strategies, the proposals are varied and encourage collective work. The subject matters are approached from questions that stimulate students' reflection, 


\section{pro.posições}

$e$-ISSN 1980-6248

http://dx.doi.org/10.1590/1980-6248-2017-0008

consideration, and the reformulation of previous knowledge. In this context, dialogue and debate are encouraged and valued, making it possible to revise concepts, expand them, or construct new meanings. In addition to reflections and debates, students are challenged to take the lead in class and, in small groups, study different didactic procedures and experience their use with other colleagues. It is important to note that there is an activity performed halfway through the semester in which students are divided into groups, so that in each there are representatives of different undergraduate courses; the main aim of this activity is to elaborate an interdisciplinary project for teaching in an elementary school, putting into practice what they have learned during the course of the semester.

The corpus of our study are the initial and final written assessments prepared by the students. In the first class, students are asked to express, in written texts, their perceptions on topics such as: the ways students learn; teaching actions; the characteristics of a good teacher; what a teacher needs to know how to teach; and what the biggest challenges faced by teachers in class are. This initial exercise has the purpose of assisting those teaching the module to identify students' concepts of these issues and help in the preparation of activities to be proposed during the development of the course. Also, this exercise enables students to become aware of and reflect on their own initial ideas about teaching and teachers. Throughout the semester, and also at the end, students are asked to elaborate various activities requiring them to synthetize the theoretical and methodological materials learned during the course. For the present study, in addition to the first assessment, the final assessment was also selected; this is an exercise in which a classroom situation was described and students were asked to critically analyse it, taking into account the performance of the teacher and the students as well as the pedagogical model in the classroom. Students are encouraged to identify positive and negative aspects of the situation and propose some changes they would make if they were the teacher. In addition to this, students must state their own concepts of teaching, learning, and evaluation, sharing all of these with their lecturer.

These documents were submitted to Textual Discursive Analysis (Moraes \& Galliazzi, 2016), a method of textual analysis, of a descriptive and interpretative character, which emphasizes the constant establishment of the relations of the parts with the whole, seeking new understandings about the subject at hand. This method allows categories to emerge a posteriori, through the analysis of the data, or a priori, set prior to the analysis of the documents. In this study, it was decided to define the categories prior to the analysis in order 


\section{pro.posıções}

$e$-ISSN 1980-6248

http://dx.doi.org/10.1590/1980-6248-2017-0008

to dialogue with the theory of Gur-Ze'ev, particularly concerning its aspects related to teacher education. Thus, Gur-Ze'ev's theory guided the construction of the following categories: (1)

Critical positioning; (2) The recognition of the other; (3) The classroom as a space for exchanges and dialogue. After establishing this, the student's texts were deconstructed to identify and isolate important and meaningful ideas, which are called "units of meaning", expressing multiple aspects referring to the theme of each of the pre-established categories. Afterwards, "rough texts" were produced contemplating the description and interpretation of the ideas present in the a priori categories. Our analysis of the arguments presented by students in the documents in conjunction with the theoretical framework provided by GurZe'ev allowed us to identify and evaluate the development of student's ideas about teaching and teachers.

\section{Results}

From Gur-Ze'ev's theory of counter-education and "improviser-teacher", we established three a priori categories: (1) Critical positioning; (2) The recognition of the other; (3) The classroom as a space for exchanges and dialogue. A summary of our analysis using these categories is given below.

\section{Critical positioning}

In the analysis of the answers of the assessment from the beginning of the semester, there was no reference to the need for developing a critical attitude in pupils, and this is probably due to student-participants' understanding that pupils can only assimilate the content that is being transmitted by the teacher. Also, there was no evidence in their responses that they were aware of the importance of critical and reflective attitudes for teachers. Their initial view of the role of the teacher is aligned to technical rationality; that is to say, it is about putting into practice the knowledge learned during their training as teachers. This seems to justify their great interest in learning teaching techniques that can be put into practice in the classroom and that supposedly guarantee student's learning during their initial training.

Throughout the duration of the semester, we sought to deconstruct these concepts in the Didactics course because, as Stenhouse (1998) argues, students, classes, and teaching 


\section{pro.posições}

$e$-ISSN 1980-6248

http://dx.doi.org/10.1590/1980-6248-2017-0008

situations are unique and, therefore, it is neither possible to predict the type of action that needs to be used nor the type of knowledge needed to account for particular situations in the classroom. Hence, we tried to reflect upon the role of the teacher through studying texts, debating, and discussing to challenge student-teachers to reflect and position themselves critically on various topics. When analysing student-participants' end-of-semester work, we noticed that a change had occurred in the student's perception because many of them had understood that the teacher's role goes beyond the mere transmission of content.

An example of this is a student-teacher's commentary stating that it is necessary to "evaluate the student's learning process during classes and not only evaluate the student's assessments. Thus, it is also possible to evaluate the teacher's performance"33. It can be argued that this understanding of evaluation is perceived as a two-way path through which the teacher will also evaluate and reflect on his or her work, and may promote changes that may improve the teaching and learning processes. This understanding is supported by Freire (2016), when he affirms that by reflecting critically on today's practice, the teacher can perfect the practice of tomorrow. Expanding on the idea of reflection as a way to improve oneself and embrace the idea of building knowledge about teaching, Pimenta and Ghedin (2012, p. 43)state that the teacher can produce knowledge from practice provided that in the course of his or her investigations he or she intentionally reflects upon it, considering the results obtained with the support of theory. Hence, upon reflecting on his or her practice, the teacher will not only improve his or her actions, he or she will also build knowledge about teaching. It is possible to overcome the limits of technical rationality because the role of the teacher is not confined to applying techniques and theories; rather, the teacher is also capable of producing knowledge. In doing so, their professional teaching identity takes a new, richer form.

The reflection on practice itself, as proposed by Schön (2000), is a first step towards overcoming the model based on technical rationality, seeking to advance students' autonomy (Feitosa \& Dias, 2017). However, we must recognise the need to expand this type of reflection, extrapolating the limits of the classroom, trying to understand the complexities involved in teaching. Authors such as Contreras (2012) and Pimenta and Ghedin (2012), have theorised on this subject, namely the reflection about the practice, suggesting that it is so fundamental that it establishes a type of identity to the teacher; that is, a teacher who is a critical and reflective individual.

\footnotetext{
${ }^{3}$ In this paper, we have translated all participants' quotations from Portuguese into English.
} 


\section{pro.posições}

$e$-ISSN 1980-6248

http://dx.doi.org/10.1590/1980-6248-2017-0008

In the analysis of the final work carried out by student-participants, it was possible to identify, besides the recognition for the need to incorporate reflection into pedagogical practice, the necessity to critically position oneself on different aspects of teaching. Also, criticisms about the traditional model of teaching was unanimous on the part of studentparticipants, and some emphasised that such a model promotes submission and acquiescence, and as such "the student does not learn to transform reality".

We note in our analysis that although their criticisms were directly related to classroom situations, and disregarded the educational context in a broader sense, it can be argued that this is an improvement if compared to their positioning at the beginning of the semester. That is, their critical positioning was practically non-existent. Thus, the critical and reflective attitude seems to develop during the unfolding of the course and in the early years of teacher education, allowing a broader and richer understanding of the educational context and of teaching.

In addition to understanding the importance of a critical and reflective attitude in teaching, most of the student-participants seem to have also perceived the need to stimulate the development of such an attitude in their future students. Being critical and developing a critical attitude in Others are characteristics of Gur-Ze'ev's “improviser-teacher". Thus, some participants have stated that "it is important for the teacher to ask questions about the topic that is being addressed so that students position themselves in relation to what has been said"; also, they affirmed that learning is "creating a critical position about some topic" or "is discovering different ways of interpreting reality itself'. It is interesting to note that one student-participant mentioned that when she takes a teaching position "she would develop activities in which students could position themselves critically in the face of historical facts".

In the same vein, another student states: "We would do an interdisciplinary project so that teaching has a holistic perspective, for the understanding of reality, enabling the formulation of critical-reflective knowledge, valuing the teaching-learning process".

These statements are evidences that prospective teachers, our student-participants, recognise that being a teacher is much more than simply transmitting content; rather, it is also about contributing to the formation of critical individuals, who can understand their reality and position themselves critically towards various issues. As such, it can be argued that the activities developed intentionally in the Didactics course during the semester seem to have 


\section{pro.posições}

$e$-ISSN 1980-6248

http://dx.doi.org/10.1590/1980-6248-2017-0008

contributed to the fact that our students felt challenged to position themselves critically and, at the same time, to realise the importance of challenging their students to be critical too. In other words, the activities developed in this course helped with the emergence and development of "improviser-teachers".

\section{The recognition of the other}

The analysis of the statements provided by the students demonstrated that changes occurred regarding their perceptions and concepts of student identity during the semester. It can be argued that this change is due to the activities developed during the course because they provoked reflections based on questions about the role of students and of teaching, as well as about learning processes.

At the beginning of the semester, most of the student-teachers referred to pupils as a homogeneous group, not recognising individuals as unique beings. In connection to this, they noted that it was important to know the group they would work with well to enable them to adapt their teaching styles to this group. For instance, one student-participant mentioned that "knowing the class is fundamental, if the class is very agitated or quieter... we have to be flexible, able to adapt, we must not to be rigid, and end up losing control". Another studentparticipant reinforces this idea by stating that to be a good teacher it is necessary "to know the group with which he or she will work, to have a plan, to know the reality and social conditions of the students of that area or community so that he or she can adapt to them".

Further, those student-participants who do refer to the pupil and not the class, manifest the importance of knowing the group in order to adapt and be able to teach them. Thus, they affirm that in order to be able to teach, it is necessary "to know the students' profile and to try as much as possible to adapt the teaching to this profile"; "To know their students, to know the best way to teach the content that will be conveyed and also to plan lessons that draw the students' attention and interest in the subject"; "Knowing the individuals, knowing their limitations, their realities and their goals"; "Knowing who the individual is, so that he or she can adapt the content to his reality".

The student-participants' responses at the beginning of the semester demonstrate that it is necessary to know the pupils and their reality in order to plan teaching activities in such a way that everyone stays interested and learns the contents. This perception is in line with the 


\section{pro.posıções}

$e$-ISSN 1980-6248

http://dx.doi.org/10.1590/1980-6248-2017-0008

initial understanding of the students-participants that students have characteristics, interests, limitations, and so on, but do not have knowledge that could be shared. In their view, it is the teacher that holds the knowledge and it is his or her responsibility to pass it on to the students as best as he or she can. In other words, it is possible to perceive that the ideas of the studentteachers are aligned with directive pedagogy, according to which, as Becker (2012, p.17) indicates, the teacher, representative of the social environment or the educational system, of the school, and of the curriculum in which the course is taught, determines that the student is a tabula rasa to all new content.

The student-participants' answers at the end of the semester show changes in their understanding of their pupils. Some seem to have overcome the idea of homogeneity and come to recognize that "each student has their own potentialities and difficulties and this must be taken into account". They also recognize that personal experiences are different and therefore "we come to school with our own experiences, and our way of being in the world is what will determine how we will learn and seek knowledge". They also point out that we "should consider people, take into consideration their life histories as well as their knowledge". These comments demonstrate that one must understand the differences that constitute each human being, and that these have implications for the school, which means that they must be considered by the teacher.

At the end of the semester, student-teachers emphasised an aspect that should be considered by the teacher when planning his or her classes; that is, the recognition that students are individuals who have knowledge. In other words, the "improviser-teacher", as conceived by Gur-Ze'ev (2007), understands the importance of considering and respecting the Other in the Other's otherness. In their answers, the student-participants affirmed that "the student already has knowledge and a life history; this is not a privilege of the teacher", and that "the teacher must take into account the knowledge of students". Thus, it could be said that some of the concepts that were manifested at the beginning of the semester began to be revised, as, for example, the initial idea of the student as a tabula rasa.

Understanding that students have knowledge implies that student-teachers must ascribe new meanings to teaching and learning, because they must reflect upon the idea of teaching as being the mere transmission of knowledge from teacher to student. Evidence for this can be found in their answers. For instance, they affirm that "to teach is to construct 


\section{pro.posıções}

$e$-ISSN 1980-6248

http://dx.doi.org/10.1590/1980-6248-2017-0008

knowledge with the student and to learn is to construct and to rebuild the knowledge with the teacher/educator", "to teach is to develop knowledge with the student, using logical connections of reasoning, and with the teacher taking on the role of mediator, allowing for the exchange of knowledge between teacher and students, and vice versa".

The perception that teaching is a one-way street, from teacher to student, seems to have changed as student-participants came to understand that "teaching, for both teacher and student, is a two-way street, where knowledge becomes effective and real, for teacher and for student, simultaneously." Furthermore, according to student-participants "teaching and learning are related because there has to be a sharing of knowledge and experiences. The teacher, as a mediator of learning, must be able to recognise and respect the student's reality to find the best way to share knowledge". The responses of the student-participants are corroborated by Freire and Faundez (2011), who affirm that it is not possible to conceive that teachers can teach without also learning something; so that if they teach, they must learn. That is to say, this is a two-way street, as was recognized by the students.

The new understanding about pupils, and consequently about the processes of teaching and learning at the end of the semester, demonstrates that student-participants seem to be departing from the idea that teaching is the mere transmission of content to the students and are starting to gain an awareness of the importance of giving opportunities to students to assume a more prominent role in the classroom. Student-participants' answers provide us with evidence for this, for instance: one of them claims that if he was a teacher today "the student would be the protagonist in class most of the time." Another one emphasizes that "he would bring contents to the context of the student, making the class more dynamic so that the development of knowledge takes place and the student stops having a supporting-actor role to become the main actor".

Thus, it is possible to show that during the unfolding of the semester ideas related to content transmission were gradually being replaced by richer ones based on the jointdevelopment of knowledge. In short, it is possible to perceive a departure from the presuppositions of directive pedagogy (Becker, 2012), since they can recognize that students are not a tabula rasa; that is, students come to school with knowledge and experiences that need to be considered by the teacher when planning activities. Student-teachers came to 


\section{pro.posições}

$e$-ISSN 1980-6248

http://dx.doi.org/10.1590/1980-6248-2017-0008

realise that knowledge cannot be transmitted but is constructed together in the relationship between teacher and pupils, in which both parties learn something.

\section{The classroom as a space for exchanges and dialogue}

In the assessment at the beginning of the semester, the importance of dialogue and exchanges in class is not present in the answers of most students. This might be due to student-teachers, at this early stage, understanding that the teacher is responsible for transmitting knowledge to pupils and for this to take place he or she must learn different techniques of teaching to make it possible to "catch the pupils" attention during class". Further, it is up to the teacher to decide the content that is to be transmitted.

This understanding is directly connected to the model of technical rationality, according to which, as Contreras (2012, p. 90) defines it, professional practice consists of the instrumental solution of problems by applying a previously available theoretical and technical knowledge that comes from scientific research. In fact, the understanding evidenced in the answers of the majority of the prospective-teacher participants at the beginning of the Didactics course is that they will learn techniques that will be applied when teaching, and which supposedly will meet the demands of the classroom.

A few responses point to another direction. One student-participant, for instance, states that it is necessary "to facilitate interaction, to provoke students, to learn from students, to make the classroom a space for experience". In the same perspective, another student emphasizes that it is up to the teacher to "make room during the lesson, even when expository, for reflection and dialogue with the students". These few answers are different from the others and allow a much richer meaning to teaching and the dynamics in the classroom.

The analysis of student-participants' answers provided by the assessment at the end of the semester demonstrated an understanding of the importance of dialogue in the classroom, which can be triggered through the interaction between teacher and pupils and between pupils themselves, establishing space for questioning and activities that stimulate discussion. Students have reflected upon the idea that only the teacher has knowledge proposing instead that pupils also have knowledge that can be shared. As we have mentioned before, in order for the GurZe'ev's "improviser-teacher" to emerge and develop there is a need for spaces that encourage 


\section{pro.posições}

$e$-ISSN 1980-6248

http://dx.doi.org/10.1590/1980-6248-2017-0008

dialogue and criticism—dialogue with the Other and criticism of external issues as well as selfcriticism.

Most of the student-participants say that they would break with the traditional model of teaching, in which the teacher is the protagonist, seeking to create a space for exchanges and dialogue between peers. They suggest that "instead of the traditional lesson, the teacher can organise a seminar, distributing texts on a particular topic and dividing pupils into groups to discuss their ideas." When asked what they would do if they had to give a class, they commented that: "I would encourage pupils to participate... and classroom discussion would take up the majority of the time"; "I would prioritise a more open model, perhaps focusing on seminars and research. I would encourage interaction between individuals, help with the development of knowledge; thus, engaging a larger number of students"; "I would pass an introductory video... or ask the students to read a book, so that everyone would talk about it later... so that the class would become more interactive". This means that the importance of establishing a favourable atmosphere for pupils to ask questions seems to have been recognized by the students. This understanding is corroborated by Freire and Faundez (2011) who argue that the construction of all knowledge begins with a question and that teachers should, first of all, teach pupils to ask questions. But this is not what usually happens, as teachers bring answers without pupils having even posed a question.

This understanding is similar to the situation in a traditional classroom that studentparticipants were asked to analyse in their final assessment. They criticised pupils for not asking questions; for instance: "no one asks questions and the teacher does not care if pupils are understanding the content properly"; "pupils should also state their doubts"; "There is little interaction with pupils, and only the teacher speaks"; "The teacher talks and the pupils listen." This criticism is corroborated by Freire and Faundez (2011) who affirm that teaching has forgotten the importance of questioning; and that both teachers and pupils have forgotten about this. Student-participants also affirmed that if teachers were to analyse the situation, then the lesson would be more interactive; they would encourage debates on specific topics, stimulate the participation of pupils and would give room for questioning. Thus, it is hoped that when these student-participants take their positions as teachers, they will be able to put into practice the knowledge constructed throughout the course regarding the understanding of the classroom as a space for dialogue, exchange of experiences and questioning. 


\section{pro.posıções}

$e$-ISSN 1980-6248

http://dx.doi.org/10.1590/1980-6248-2017-0008

\section{Conclusion}

At the beginning of the Didactics course, our idea was to propose experiences during the semester that could promote a "thinking about" attitude in our students, to challenge them to revise their concepts about teaching and about the profession in light of the theory, so that they could achieve broader and richer levels of conceptualisation. We understand that this can greatly contribute to the constitution of their professional teaching identity.

The analysis of the study's corpus evidenced significant changes in the students' initial concepts, which are in line with the a priori categories based on Gur-Ze'ev's theory of countereducation and "improviser-teacher". Thus, the categories considered in this study are: (1) Critical positioning; (2) The recognition of the other; (3) The classroom as a space for exchanges and dialogue. There is remarkable evidence from the analysed data demonstrating that the activities developed in the Didactics course helped with the emergence of what GurZe'ev would call the "improviser-teacher". That is, the kind of teacher that encourages criticism and self-criticism, that recognises the importance of considering the Other for education, and that recognises the importance of dialogical spaces for this to happen.

Gur-Ze'ev's theories - counter-education and the 'improviser-teacher' - help us understand the importance of some fundamental characteristics that need to be present in education and developed by teachers if education is to be effective, forming individuals who are critical of their reality and of their own attitude, respectful of Others, and that are engaged in the development of dialogical spaces. All these aspects have implications that go beyond the classroom and school; that is to say, it can be argued that they encourage ethical and political attitudes based on critical thinking, respect for differences, and the creation of democratic structures that support them. Therein lies the importance of Gur-Ze'ev's "counter-education" and "improviser-teacher" theories. 


\section{pro.posıções \\ $e$-ISSN 1980-6248}

\section{References}

Alarcão, I. (Org.). (2000). Escola reflexiva e nova racionalidade. Porto Alegre, RS: Artmed.

Becker, F. (1994, janeiro/junho). Modelos pedagógicos e modelos epistemológicos. Educação e Realidade, 19(1), 89-96.

Becker, F. (2012). Educação e construção do conbecimento (2a ed.). Porto Alegre, RS: Penso.

Beja, A. C., \& Rezende, F. (2014). Processos de construção da identidade docente no discurso de estudantes da licenciatura em química. Revista Electrónica de Enseñanz̧a de las Ciencias, 13(2), 156-178.

Contreras, J. (2012). A autonomia de professores (2a ed.). São Paulo, SP: Cortez.

Denzin, N. K., \& Lincoln, Y. S. (2006). Handbook of qualitative research, Thousand Oaks, CA: Sage Publications.

Feitosa, R. A., \& Dias, A. M. (2017). Décadas do surgimento do practicum reflexivo: por teoria(s) e prática(s) articuladas na formação e na ação docentes. In A. S. Neto, \& I. Fortunato (Orgs.), 20 anos sem Donald Schön: o que aconteceu com o professor reflexivo? (pp. 13-32). São Paulo, SP: Hipótese.

Flick, U. (2009). Uma introdução à pesquisa qualitativa (S. Netz, Trad.). Porto Alegre: Bookman.

Fonte, P. (2014). Pedagogia de projetos: ano letivo sem mesmice. Rio de Janeiro, RJ: Wak.

Freire, P. (2016). Pedagogia da autonomia: saberes necessários à prática educativa (53a ed.). São Paulo, SP: Paz e Terra.

Freire, P., \& Faundez, A. (2011). Por uma pedagogia da pergunta. São Paulo, SP: Paz e Terra.

Fusari, J. C. (1990). O planejamento no trabalho pedagógico: algumas indagações e tentativas de respostas. Ideias, 72, 44-58. Recuperado em 20 de março de 2016, de http://www.crmariocovas.sp.gov.br/pdf/ideias_08_p044-053_c.pdf

Gómez, A. I. P. (2015). Educação na era digital: a escola educativa. Porto Alegre, RS: Penso.

Grillo, M. C. (2001). O professor e a docência: o encontro com o aluno. In D. Enricone (Org.), Ser professor (pp. 73-90). Porto Alegre, RS: EDIPUCRS. 


\section{pro.posıções}

$e$-ISSN 1980-6248

http://dx.doi.org/10.1590/1980-6248-2017-0008

Guba, E., Lincoln, Y. (1994). Competing paradigms in qualitative research. In N. Denzin, \& Y. Lincoln (Ed), Handbook of qualitative research (pp. p. 105-117). Thousand Oaks, CA: Sage Publications.

Gur-ze'ev, I. (2002). É possível uma educação crítica no ciberespaço? Revista Comunicações, 9(1), 72-98.

Gur-ze'ev, I. (2005). Critical theory and critical pedagogy today: Toward a new critical language in education. Haifa, Israel: Studies in Education.

Gur-ze'ev, I. (2006). A Bildung e a Teoria Crítica na era da educação pós-moderna. Linhas Criticas, 12(22), 5-22.

Gur-ze'ev, I. (2007). Beyond the modern-postmodern struggle in education: Toward counter-education and enduring improvisation. Rotterdam: Sense Publishers.

Gur-ze'ev, I. (2010a). Introduction. Diasporic philosophy and counter education (pp. 11-28). Rotterdam: Sense Publishers.

Gur-ze'ev, I. (2010b). The nomadic existence of the eternal improviser and diasporic copoiesis today. Diasporic philosopby and counter education (pp.29-46 ). Rotterdam: Sense Publishers.

Gur-ze'ev, I. (2011). The Nomadic existence of the eternal improviser and diasporic co-poiesis in the era of mega-speed. Diasporic philosophy and counter-education (pp. 29-45). Rotterdam: Sense Publishers.

Hernández, F. (1998). Os projetos de trabalho: uma forma de organizar os conhecimentos escolares. Porto Alegre, RS: Artmed.

Kollas, F., Marques, R., Megier, A. P. A., \& Frison, M. D. (2013, setembro/dezembro). Saberes necessários ao bom professor: dizeres de licenciandos e estudantes da Educação Básica. Revista de Educação, (38), 645-657.

Lima, V. M. R., \& Grillo, M. (2008). O fazer pedagógico e as concepções de conhecimento. In M. C. Grillo, A. L. S. Freitas, R. M. Gessinger, \& V. M. R. Lima (Orgs.). A gestão da aula universitária na PUCRS (pp. 21-31). Porto Alegre, RS: EDIPUCRS.

Liston, D. P., \& Zeichner, K. M. (1997). Formación del profesorado y condiciones sociales de la escolarización. Madrid, Espanha: Morata. 


\section{pro.posıções}

$e$-ISSN 1980-6248

http://dx.doi.org/10.1590/1980-6248-2017-0008

Moraes, R., \& Galliazzi, M. C. (2016). Análise textual discursiva (3a ed.). Ijuí, RS: UNIJUÍ.

Morosini, M. C., \& Comarú, P. do A. (2009). A dimensão profissional docente: questões do nosso tempo. In D. Enricone (Org.), Professor como aprendir: saberes docentes (pp. 61-92). Porto Alegre, RS: EDIPUCRS.

Nóvoa, A. (1995). Vida de professores. Porto, Portugal: Porto Editora.

Pimenta, S. G. (Org.). (2012). Saberes pedagógicos e atividade docente (8a ed.). São Paulo, SP: Cortez.

Pimenta, S., \& Ghedin, E. (Org.). (2012). Professor reflexivo no Brasil: gênese e crítica de um conceito (7a ed.). São Paulo, SP: Cortez.

Porlán, R. (1998). Constructivismo y escuela: Hacia un modelo de enseñanza-aprendizaje basado en la investigación. Sevilla, Espanha: Díada.

Porlán, R., \& Rivero, A. (1998). El conocimiento de los profesores. Sevilla, Espanha: Díada.

Puentes, R.V., Aquino, O. F., \& Armindo, Q. N. (2009). Profissionalização de professores: conhecimentos, saberes e competências necessárias à docência. Educar, 34, 69-184.

Schön, D. (2000). Educando o profissional reflexivo: um novo design para o ensino e a aprendiragem. Porto Alegre, RS: Artmed.

Shulman, L. S. (2005). Conocimiento y enseñanza: fundamentos de la nueva reforma. Revista de Curriculum y formación del profesorado, 9(2), 1-30. Recuperado em 23 de março de 2016, de http:/ /recyt.fecyt.es/index.php/profesorado/article/view/42831/24722.

Stake, R. E. (2011). Pesquisa qualitativa: estudando como as coisas funcionam (K. Reis, Trad.). Porto Alegre/RS: Penso/Artmed.

Stenhouse, L. (1998). La investigación como base de la enseñanza. Madrid, Espanha: Morata.

Tardif, M. (2002). Saberes docentes e formação profissional. Petrópolis, RJ: Vozes.

Triviños, A. (1978). Introdução à pesquisa em ciências sociais: a pesquisa qualitativa em educação. São Paulo: Atlas.

Tubbs, N. (2005). The philosophy of critical pedagogy. In I. Gur-Ze'ev (Ed.), Critical theory and critical pedagogy today: Toward a new critical language in education (pp. 226-240). Haifa, Israel: Studies in Education. 


\section{pro.posições $e$-ISSN 1980-6248 \\ http://dx.doi.org/10.1590/1980-6248-2017-0008}

Yaakoby, T. (2012). A critical examination of neo-Marxist and postmodernist theories as applied to education. Münster, New York, München and Berlin: Waxmann.

Submitted in January 17, 2017; approved for publication in November 24, 2017. 